\title{
More than a Million Elephants - but They Face Extinction
}

Can an animal which still numbers around $1,343,000$ be considered endangered? This was the problem faced by IUCN's Survival Service Commission when it held its 53rd meeting in Kenya in April. There are still elephants in 35 African countries, but in 27 of them stocks are declining. Only five countries have an elephant density of more than one per five square kilometres. Four of these are grouped together in south central Africa: Zambia, Tanzania, Zimbabwe and Malawi, with a total of just over half a million elephants between them. Zaire has more elephants than any other African country, but its estimated 377,700 animals are spread out over its huge area of nearly 2 million sq $\mathrm{km}$. The most serious plight is that of the Uganda elephants, now well on their way to extinction because, as the head of the Uganda Institute of Ecology, Dr Eric Edroma, told the meeting, the poachers were in control of the parks.

The elephant must be considered in danger of extinction in the wild before the end of the century if trends that apply to the whole of Africa are not reversed. The root of the trouble is the high price of ivory since the world instability of money following the 1973 oil-price hike. A kilogram of ivory was worth $\$ 7.25$ in the 1960 s, but $\$ 74$ in 1979 . World exports of African ivory (there is little Asian ivory in trade because so few Asian elephants are left) have multiplied ten times to over a million $\mathrm{kg}$ a year. In recent years four-fifths of this has ended up in either Japan or Hong Kong.

These facts, of elephant populations and the ivory trade, come from the two IUCN/WWF enquiries, conducted most ably by Iain Douglas-Hamilton and Ian Parker respectively, which formed the background to the SSC meeting. IUCN/WWF is not against a legitimate trade where stocks can stand it, for rogue animals have to be eliminated. The problem is to prevent illegal elephant-killing destroying populations, as has happened in many parts of East Africa in recent years. IUCN/WWF plans a four-pronged approach to this major wildlife conservation problem:

1. to request Governments to cooperate in closing the loopholes which allow ivory smuggling to take place and apprehending the culprits, some of whom are known to occupy official positions;

2. to promote the strengthening of CITES, the Convention on International Trade in Endangered Species. In this connection the recent adhesion of Hong Kong and imminent adhesion of Japan should greatly help to stamp out illegal ivory trade. Specific measures to be explored include standardising trade documents and making them forgery-proof, marking exported raw ivory, and establishing a scientifically based ivory export quota for each exporting country;

3. to promote elephant conservation in the field, with projects for strengthening national parks, equipping park rangers and anti-poaching units, training wildlife staff and educating the African public, especially young people, through wildlife clubs and in other ways;

4. and last, but not least important, to attempt to understand and influence the ivory trade. No legitimate trader is unmindful of the public relations aspects of his trade, and legitimate traders will always cooperate in reasonable 
measures designed to safeguard their future sources of supply. It is difficult for them to do this while illegitimate traders are making huge profits on the side.

WWF's Elephant Appeal is expected to raise over $\$ 1$ million, and it will take all this and more to tackle this programme with some chance of success. At the same time elephants in Africa can only be saved if the African people want them saved. Education at all levels on the value of living resources is obviously vital.

\section{Selling Rhinos to Extinction}

There is no doubt that the world's rhinos are being hunted to extinction for their horn, the price of which has gone up twenty-fold in the last five years. In the whole of Africa rhinos are now estimated to number between 14,000 and 20,000; Asian rhinos are put at about 2000. Yet in 1969 Kenya alone had at least 18,000; in 1979 the figure was 1500 . In three East African countries, Kenya, Uganda and Tanzania, the decrease in rhinos in that period is put at 90 per cent, and nearly 24 tonnes of horn were exported officially between 1970 and 1976 - the product of over 8000 rhinos. (An equal amount is believed to have been smuggled out.) So a major cause for the decline in rhinos is easy to see. Where does it all go?

Esmond Bradley Martin has done a major investigation into the trade and what parts are involved, where and how they are used, and prices. He calculates that more than 2500 rhinos were killed every year between 1972 and 1978 to support the trade. That could mean extinction in ten years. Much of East African horn goes to China and the traditional medicine shops in south-east Asia which are almost exclusively owned by Chinese, where it is used as a fever-reducing drug, 'sold over the counter along with the aspirin and antiobiotics', and not, as is widely believed, as an aphrodisiac. Only in India, he says, is it used for this purpose, mainly in Gujerat (African horn) and Bengal (Indian horn).

The other major demand for African horn, and one that has arisen largely in the past ten years, is in North Yemen to make handles for daggers (jambias). Income per head in North Yemen has risen from $\$ 18$ to $\$ 500$ since 1962 , thanks to jobs in Saudi Arabia, and Yemenis can now afford the $\$ 300-\$ 13,000$ that the much coveted rhino-horn handles cost. Dr Martin points out that

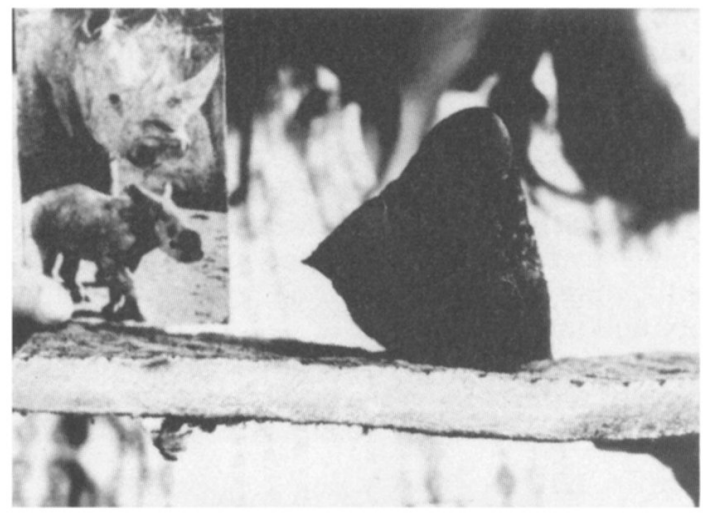

Rhino horn and a slice of unprocessed skin on display in a Chinese pharmacy

Photographs: Esmond B. Martin 